\title{
Buffel grass in Queensland's semi-arid woodlands: response to local and landscape scale variables, and relationship with grass, forb and reptile species
}

\author{
Teresa J. Eyre ${ }^{\mathrm{A}, \mathrm{D}}$, Jian Wang ${ }^{\mathrm{A}}$, Melanie F. Venz ${ }^{\mathrm{A}}$, Chris Chilcott ${ }^{\mathrm{B}}$ and Giselle Whish ${ }^{\mathrm{C}}$ \\ ABiodiversity Sciences Unit, Queensland Department of Resource Management, Forestry Building, 80 Meiers Road, \\ Indooroopilly, Qld 4068, Australia. \\ ${ }^{B}$ Department of Agricultural and Food, 3 Baron-Hay Court, South Perth, WA 6058, Australia. \\ ${ }^{C}$ Department of Primary Industries and Fisheries, 203 Tor Street, Toowoomba, Qld 4350, Australia. \\ DCorresponding author. Email: teresa.eyre@derm.qld.gov.au
}

\begin{abstract}
Buffel grass [Pennisetum ciliare (L.) Link] has been widely introduced in the Australian rangelands as a consequence of its value for productive grazing, but tends to competitively establish in non-target areas such as remnant vegetation. In this study, we examined the influence landscape-scale and local-scale variables had upon the distribution of buffel grass in remnant poplar box (Eucalyptus populnea F.Muell.) dominant woodland fragments in the Brigalow Bioregion, Queensland. Buffel grass and variables thought to influence its distribution in the region were measured at 60 sites, which were selected based on the amount of native woodland retained in the landscape and patch size. An information-theoretic modelling approach and hierarchical partitioning revealed that the most influential variable was the percent of retained vegetation within a $1-\mathrm{km}$ spatial extent. From this, we identified a critical threshold of $\sim 30 \%$ retained vegetation in the landscape, above which the model predicted buffel grass was not likely to occur in a woodland fragment. Other explanatory variables in the model were site based, and included litter cover and long-term rainfall. Given the paucity of information on the effect of buffel grass upon biodiversity values, we undertook exploratory analyses to determine whether buffel grass cover influenced the distribution of grass, forb and reptile species. We detected some trends; hierarchical partitioning revealed that buffel grass cover was the most important explanatory variable describing habitat preferences of four reptile species. However, establishing causal links - particularly between native grass and forb species and buffel grass - was problematic owing to possible confounding with grazing pressure. We conclude with a set of management recommendations aimed at reducing the spread of buffel grass into remnant woodlands.
\end{abstract}

Additional keywords: clearing, fragmentation, grassy woodlands, invasive grass, thresholds.

\section{Introduction}

Frequent droughts during the early 1900s in northern Australia, Africa and North and South America compelled a worldwide search for a grass that could produce good forage for livestock with limited precipitation (Cox et al. 1988). The search ended with the discovery of several native grass species of southern Asia and East Africa, buffel grass [Pennisetum ciliare (L.) Link] being one of them. Buffel grass was subsequently introduced in northern Australia during the 1920s, and Texas (USA) and northern Mexico in the 1930s (Mayeaux and Hamilton 1983; Cox et al. 1988; Arriaga et al. 2004). In Queensland, buffel grass was first sown in Cloncurry in 1926, and then in the Rockhampton district in 1928 (Humphreys 1967). By the early 1930s experimental sowing of buffel grass were made in several Queensland districts, and seed from several cultivars have since been introduced to increase adaptability (Paull and Lee 1978).

The adaptive capacity of buffel grass in the arid and semi-arid tropics is unequivocal. Buffel grass produces large quantities of light, bristled viable seeds asexually, which are effectively dispersed via wind, water and animals. Aggressive expansion of rhizomes, effectively forming dense swards, also assists colonisation (Humphries et al. 1991). Since its introduction to the Sonoran Desert, Mexico, buffel grasslands now extend throughout an estimated $12 \%$ of the area (Búrquez-Montijo et al. 2002). This largely reflects the deliberate conversion of desert native vegetation to buffel grass pasture land, the area of which has effectively doubled approximately every 10 years since 1973 in the region (Franklin et al. 2006). However, buffel grass tends to occupy non-target ecosystems adjacent to pasturelands in this region (Búrquez-Montijo et al. 2002). In Texas, through sowing and natural dispersion, buffel grass occupied $\sim 90 \%$ of rangelands within 40 years (Mayeaux and Hamilton 1983). On O'ahu, Hawaii, $33 \%$ of the native grasslands have been transformed to buffel grasslands within a 30-year period (Daehler and Carino 1998). In central Australia, quantitative long-term monitoring has shown an increase in buffel grass relative abundance from $5 \%$ to 
more than $80 \%$ in less than 30 years (Clarke et al. 2005), and drainage systems and alluvial flats appear to be most at risk (Griffin 1993). Although buffel grass has now been recorded throughout much of arid and semi-arid Australia (Low 1999), the current extent of buffel grassland in Australia is unknown. However, $\sim 68 \%$ of the country is predicted to be potentially suitable for buffel grass establishment (Lawson et al. 2004).

The ecology, and invasive capacity, of buffel grass has been studied in relation to rainfall variability and drought (Fitzgerald 1955; Sheriff and Ludlow 1984; Clarke et al. 2005), competition with established native vegetation (McIvor 2003; Clarke et al. 2005; Jackson 2005), tree canopy interactions (Christie 1975a), edaphic characteristics (Cox et al. 1988; Griffin 1993; Ibarra et al. 1995; Arriaga et al. 2004; Lawson et al. 2004), fire (Mannetje et al. 1983; Butler and Fairfax 2003) and grazing disturbance (Hodgkinson et al. 1989). These studies profile buffel grass as an extremely competitive species, with a high resistance to fire, drought and heavy grazing, particularly in arid and semi-arid regions. Consequently, buffel grass is a valued pasture improvement species, and continues to be the most widely sown pasture grass in Queensland (Cavaye 1991; McIvor 2003).

Conversely, buffel grass is also identified as one of the most widespread non-native plant species potentially posing a threat to rangeland biodiversity (Humphries et al. 1991; Grice 2004, 2006; Martin et al. 2006). However, there have been few studies that have quantified the impact of buffel grass establishment upon biodiversity in Australia. Most studies report a negative relationship between buffel grass biomass or cover and plant species richness and/or individual plant species cover (McIvor 1998; Fairfax and Fensham 2000; Franks 2002; Butler and Fairfax 2003; Clarke et al. 2005; Jackson 2005; Kaur et al. 2006; Smyth et al. 2009). The impacts upon fauna species are largely unknown, although it is generally surmised to be extremely detrimental (Low 1997). Of the few quantitative studies, Ludwig et al. (2000) report mammal and reptile species' decline with increased buffel grass cover in central Queensland. For bird species, a mixed response has been reported, with some species being negatively associated and others being positively associated with buffel grass extent (Hannah et al. 2007). In Arid Australia, ground dwelling bird species were found to be negatively associated with increased buffel grass cover, possibly through limiting foraging prospects (Smyth et al. 2009). There is some evidence to suggest that the 'hot climate specialist' functional group of ants are also adversely affected by encroachment of buffel grass (Smyth et al. 2009).

The study presented in this paper was conducted in the Maranoa region of south-west Queensland, one of three main buffel grass areas in Queensland (Paull and Lee 1978). In this region, it was estimated in 1991 that at least 1 million ha had been actively sown to buffel, resulting in pure buffel swards or mixtures with native grasses (Cavaye 1991). This constitutes a $50 \%$ increase from estimates made in the mid 1970s (Paull and Lee 1978; Cavaye 1991). We focussed our study in the remnant grassy poplar box (Eucalyptus populnea F.Muell.) woodlands, which in general are utilised for grazing but have not been subjected to the deliberate seeding of buffel grass. No previous study has yet endeavoured to detect thresholds for management of invasive risk of buffel grass into remnant vegetation. As such, the aim of this study was to: (i) identify the relationship between buffel grass and local- and landscape-scale environmental, habitat and disturbance variables; and (ii) identify vegetation clearing thresholds beyond which buffel grass is likely to invade remnant vegetation.

Inconsistent responses of various species to disturbances such as grazing pressure is known to occur at the continental, and even regional, scale (Vesk and Westoby 2001; McIntyre et al. 2003). A similar species response may be observed with the introduction or invasion of buffel grass, especially since invasion generally occurs in combination with other disturbances such as increased grazing pressure and native vegetation clearing. Given the concern regarding buffel grass spread and impact in Australia has been relatively recent, information is limited for meta-analysis of native species' response to buffel grass throughout Australia. As such, a third aim of this paper was to identify any trends in relationships between native ground layer plant species cover abundance or reptile species occupancy and buffel grass cover abundance in remnant vegetation.

\section{Materials and methods}

\section{Study area and site selection}

The study area incorporates 4.5 million ha of the Maranoa district within the Brigalow Bioregion of south-west Queensland (Fig. 1). The annual average rainfall is between 500 and $750 \mathrm{~mm}$ across the study region, the majority $(>70 \%)$ of which occurs during October-March. State forests and conservation reserves occupy $\sim 5$ and $1 \%$ of the study area, respectively. The principal land use in the study region is agriculture, predominantly cattle and sheep grazing with opportunistic cropping in favourable seasons. Prior to the cessation of broadscale clearing in Queensland through amendment of the Vegetation Management Act 1999, 70\% of the original vegetation was cleared and is now grazed native pasture and non-remnant (regrowth) woodland. The establishment of buffel grass pasture through aerial or on-ground sowing accompanied the majority of vegetation clearing in the region (Cavaye 1991; Fairfax and Fensham 2000).

Of the total study area, $32 \%$ is covered by remnant forest and woodland, of which $\sim 40 \%$ is mapped as poplar box dominant or co-dominant woodland (EPA 2003). The poplar box woodlands were the ecosystem type targeted by this study. We wanted to assess the potential of buffel grass to occur in remnant woodland in fragmented landscapes. Poplar box dominant remnants were mapped in the study region using 1:100000 remnant regional ecosystems mapping (EPA 2003), and potential sites were located on candidate properties and access permissions sought. We used native woody cover derived by the Statewide Land and Tree Study (SLATS; NRM 2003) to identify levels of fragmentation in the landscape of each potential site, where a landscape was defined as a $5-\mathrm{km}$ circular spatial extent radiating from the centre of the site. The extent of native woody cover in each landscape was then calculated using Geographical Information System software ArcGIS (Version 9.1; ESRI 2005). Botanical nomenclature according to Bostock and Holland (2007) is used throughout this paper.

Sites were selected to sample poplar box remnants in five broad landscape treatments typical of the region. These were; small fragments $(<50 \mathrm{ha})$ in relictual landscapes $(<15 \%$ retained vegetation in the landscape); small fragments in fragmented 


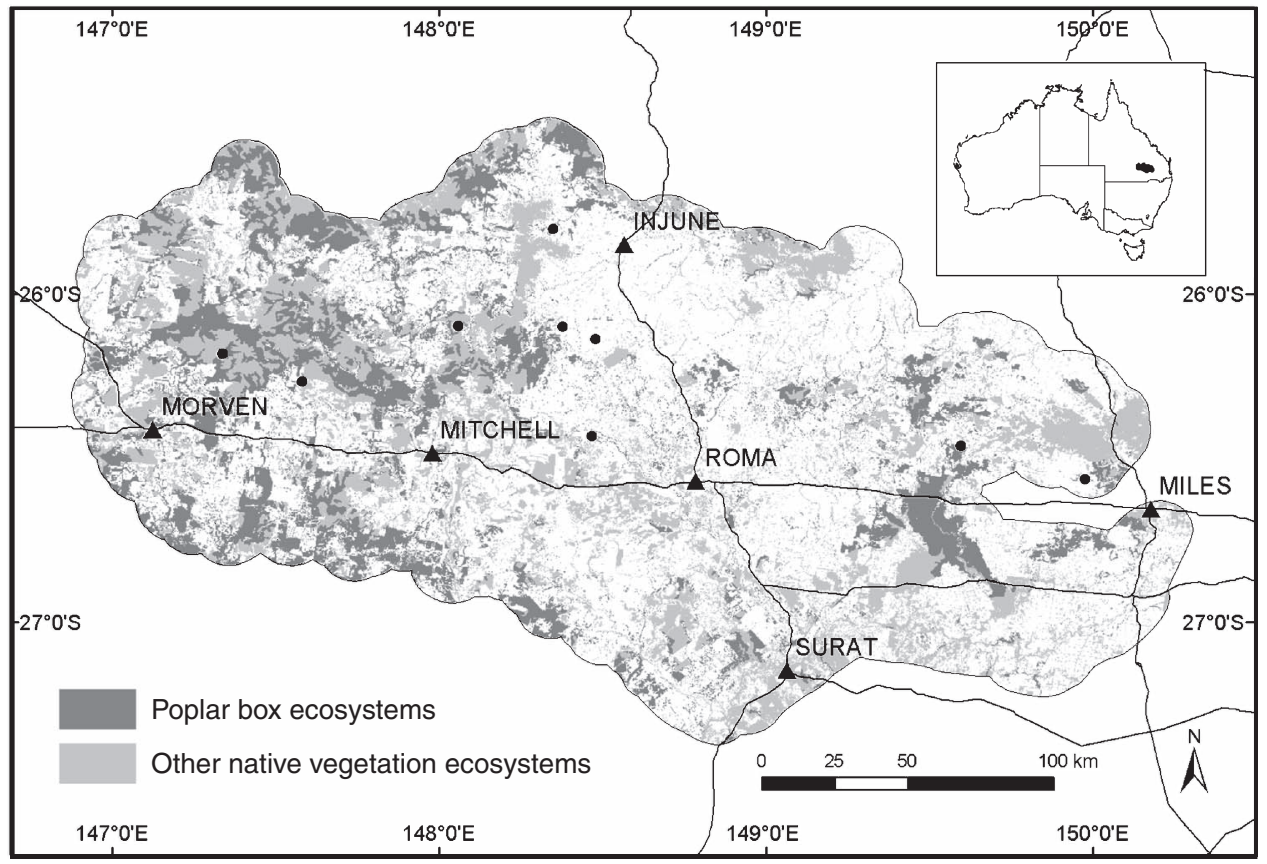

Fig. 1. The study area and location of survey sites.

landscapes (15 to $70 \%$ retained vegetation in the landscape); medium fragments (50-200 ha) in fragmented landscapes; large fragments (>200 ha) in fragmented landscapes; and large fragments in intact landscapes $(>70 \%$ retained vegetation in the landscape).

Twelve replicates were sampled for each landscape-scale treatment type, resulting in a total of 60 sites (Fig. 1). In the field, sites were ground truthed for suitability. Suitable sites were located at least $2 \mathrm{~km}$ apart to avoid issues of spatial autocorrelation, and $500 \mathrm{~m}$ away from artificial water points. Riparian areas were avoided, and sites were located within the remnant at least $100 \mathrm{~m}$ from the edge where possible.
Local-scale variables

Several vegetation structure and environmental variables thought to influence occupancy of remnant vegetation by buffel grass were measured within a $100 \times 10 \mathrm{~m}$ plot at each site between March and November 2003 (Table 1). Twenty soil cores $(0-100 \mathrm{~mm})$ were collected and bulked at each site and sampled for nitrogen. Litter cover was visually assessed by recording the percent cover of each within ten $1 \times 1 \mathrm{~m}$ quadrats located along the central $100 \mathrm{~m}$ transect and averaged for the site. Projected foliage cover was measured as the percentage of ground area occupied by the vertical projection of foliage and branches of live tallest and mid-strata stems. The vertical interception of

Table 1. Description of environmental variables recorded for each site

\begin{tabular}{|c|c|}
\hline Variable code & Description \\
\hline \multicolumn{2}{|r|}{ Local-scale variables } \\
\hline SoilN & Total nitrogen of soil sample $(\%)$ \\
\hline Precip & Mean annual rainfall averaged over 30 years data $(\mathrm{mm})$ \\
\hline PFC & Percentage of ground area occupied by the vertical projection of live foliage and branches of mid and tallest strata (\%) \\
\hline CWD & Volume of coarse woody debris $>10 \mathrm{~cm}$ diameter, derived using the formula by Van Wagner $(1968)\left(\mathrm{m}^{3} \mathrm{ha}^{-1}\right)$ \\
\hline Litter & Percentage of ground area occupied by fine to coarse fallen organic litter such as leaves, twigs and branches $<10 \mathrm{~cm}$ diameter $(\%)$ \\
\hline Fire & 0, no fire; 1 , cool burn, scorch height up to $1 \mathrm{~m}$ on trees, tree canopy not scorched; 2 , hot burn, tree canopy scorched \\
\hline Graze & $\begin{array}{l}\text { Categorised as 1, nil to light grazing, typical in national parks and state forests, swards intact and history of little or infrequent grazing; } \\
\text { 2, moderate grazing, typical in grazed paddocks and stock routes, selective grazing obvious and history of moderate grazing; and } \\
\text { 3, heavy grazing, typical in grazed paddocks, bare ground and/or closely cropped areas apparent, decreaser native pasture species } \\
\text { such as Themeda triandra absent }\end{array}$ \\
\hline \multicolumn{2}{|r|}{ Landscape-scale variables } \\
\hline Veg1k & Extent of native vegetation retained within 1-km spatial extent $(\%)$ \\
\hline Buffel landtype & Extent of brigalow-belah and softwood vine scrub landtypes cleared and sown to buffel within a 1-km spatial extent (\%) \\
\hline Near neighbour & Mean shortest straight-line distance between the focal vegetation patch and the nearest neighbour vegetation patch (m) \\
\hline IJI & Interspersion and juxtaposition index of the extent to which all vegetation patches in the landscape are equally adjacent to each other \\
\hline
\end{tabular}


foliage was recorded at $1-\mathrm{m}$ intervals along the $100 \mathrm{~m}$ transect using a gimbal ring sighting tube. The volume of coarse woody debris (CWD) at each site was estimated using the line-intersect methodology described by Van Wagner (1968). The diameter of fallen branches and trees $>10 \mathrm{~cm}$ and $>0.5 \mathrm{~m}$ in length that intercepted a $100 \mathrm{~m}$ transect centred on the plot was recorded and applied to the formula:

$$
\mathrm{V}=\left[(\pi)^{2} / 8 L\right] \times \Sigma(d)^{2}
$$

where $L$ was the transect length $(100 \mathrm{~m})$ and $d$ was the diameter of the CWD in $\mathrm{m}$.

Data on annual precipitation over the past years (1975-2003) were obtained for each site from the SILO national interpolated climate surfaces (Jeffrey et al. 2001), and averaged to give one value per site. Grazing pressure was rated from 1 (light grazing) through to 3 (heavy grazing) as estimated from landholder questionnaires on stocking history and visual observations. Fire intensity was also assessed from landholder surveys and measured evidence of burning at each site (Table 1).

\section{Landscape-scale variables}

A core set of four uncorrelated landscape-scale candidate variables were generated for the modelling procedure (Table 1). Each survey site was buffered in ArcGIS (ESRI 2005) using a $1-\mathrm{km}$ radius from the centre of the site to create a circular spatial extent encompassing $\sim 314$ ha. This spatial extent was then intersected with the SLATS woody vegetation cover to derive data on the proportion of vegetation retained.

We also intersected the $1-\mathrm{km}$ spatial extent with land types highly suitable for buffel grass establishment post-clearing. These land types have been identified as Brigalow Belah Scrub and Softwood Vine Scrub, which were preferentially sown to buffel following clearing in southern Queensland (Chilcott et al. 2004). We made the cleared, buffel land types spatial by matching them to regional ecosystem types, and then using the pre-clear $1: 100000$ regional ecosystem mapping (EPA 2003) to derive their original extent in hectares. This original extent, minus the remnant extent of the regional ecosystems, provided an estimate of the area of land types preferentially sown to buffel grass within a $1-\mathrm{km}$ radius of our sites.

Landscape metrics were generated for each site using FRAGSTATS version 3.3 (McGarigal et al. 2002) and the remnant regional ecosystem and SLATS mapping. FRAGSTATS produced a large number of metrics, many of which were difficult to interpret for management purposes. Others, such as patch area and patch shape, were highly correlated with each other and with the proportion of vegetation retained in the landscape. We, therefore, opted to retain only two FRAGSTAT metrics, the interspersion and juxtaposition index and nearest neighbour (Table 1).

\section{Ground cover and reptile survey}

Data on ground cover plant species and reptile species were obtained for each of the 60 sites between November 2002 and January 2004. The percentage cover of buffel grass and other ground cover species were visually assessed once from ten $1 \times 1 \mathrm{~m}$ quadrats which were aligned $10 \mathrm{~m}$ apart along the centre transect. The percentage cover values were averaged across the
10 quadrats to give one percentage cover value for each species per site. For each site, four active searches for reptiles were conducted within a $200 \times 50 \mathrm{~m}$ area, incorporating one morning and one afternoon search within adjacent $100 \times 50$ m areas during summer-autumn and repeated during a second visit period in spring-summer. These data were pooled to give a presence or absence value for each species per site.

\section{Statistical analyses}

One-way analysis of variance (ANOVA) was used to investigate any significant difference in the mean cover of buffel grass between sites on the various land tenures (freehold, leasehold, travelling stock routes and national parks and state forests combined) and the three categories of grazing pressure. One-way ANOVA was also used to test for mean differences in number of native ground cover species and reptile species among classes of buffel grass cover. Since the averaged estimates of buffel grass cover per site were quite low, we selected three cover classes to reflect this; zero cover; $0.1-5 \%$ cover and; $>5 \%$ cover. Tukey's pairwise comparison tests were performed when significant differences were found. Prior to the analyses, the dependent variables were normalised using a log-transformation.

An information-theoretic approach (Burnham and Anderson 2002) was used to test the hypothesis that local- and landscapescale variables influence buffel grass occupancy in poplar box woodlands. The information-theoretic approach allows comparison of fit between a suite of competing models using Akaike's information criterion (AIC). Models can then be ranked in order of decreasing AIC values, indicating increased model fit. Thus, we developed a set of models to evaluate the hypothesis that local-scale and landscape-scale variables influence buffel grass occupancy in poplar box woodlands. As this study had a small sample size, we evaluated the information content of the models using the second order $\mathrm{AIC}, \mathrm{AIC}_{\mathrm{c}}$, which balances the fit of a maximum-likelihood least-squares model $[\log (L)]$ against the number of estimable parameters in the model $(K)$. Level of support for each model was evaluated using the difference between the $\mathrm{AIC}_{\mathrm{c}}$ of a given model and the $\mathrm{AIC}_{\mathrm{c}}$ of the model with the smallest $\operatorname{AIC}_{\mathrm{c}}\left(\Delta_{i}\right)$. Additionally, Akaike weights $\left(w_{i}\right)$ were calculated for each model, as:

$$
w_{i}=\exp \left(-0.5 \Delta_{i}\right) / \Sigma\left[\exp \left(-0.5 \Delta_{i}\right)\right]
$$

To reduce bias and increase precision, we used multi-model inference or model averaging where we were unable to determine a model that best fit the data (i.e. $\Delta_{i}<2$ or $w_{i}>0.1$ ) (Burnham and Anderson 2002). Hierarchical partitioning was used to identify the explanatory variables that explained the most variance independently of the others in the final model.

Logistic regression with a logit-transformation, a form of generalised linear model (McCullagh and Nelder 1989) was used to estimate the response between the presence or absence of buffel grass and the candidate set of local- and landscape-scale variables. The logistic regression model fits an S-shaped curve to binary data and follows the form:

$$
\operatorname{Logit}(p)=\log (p / 1-p)=\beta_{0}+\beta_{1} x_{i 1}+\ldots \beta_{p} x_{i p}
$$

where the response variable $p$ is constrained between 0 (absence) and 1 (presence), thus, the error structure is specified by the 
binomial distribution (Hosmer and Lemeshow 2000). Models were developed and model AIC determined using the R statistical package (version 2.6.0; R Development Core Team 2007). Model-averaging of model combinations of the most plausible variables was conducted using the Bayesian model averaging (BMA) package in R (Raftery et al. 2006), and the hierarchical partitioning was undertaken using the hier.part package, also in $\mathrm{R}$ (Walsh and Mac Nally 2007).

Prior to the modelling procedure, the candidate variables were checked for normality, using normal probability plots. It is important to ensure no highly correlated explanatory variables exist with a model, as a lack of independence between the explanatory variables within a multivariate model violates an important assumption of regression analysis, and can lead to unreliable selection of the most appropriate explanatory variables (Mac Nally 2000). Hierarchical partitioning provides a mechanism to identify those explanatory variables that explain most variance independently of the others, thus overcoming issues of multi-collinearity between explanatory variables (Mac Nally 2002).

Model performance was assessed using the receiver operating characteristic (ROC) curve, where sensitivity values (the proportion of observations where the model correctly predicts presence) are plotted against false positive values $(1-$ the proportion of observations where the model correctly predicts absence) (Metz 1978; Zweig and Campbell 1993). The ROC curve provides a graphical approach to the assessment of model discrimination capacity, where perfect discrimination is represented when the curve follows the left hand and top axes of the graph area, and the area under the ROC curve (AUC) equals 1 (Zweig and Campbell 1993). When there is no discrimination capacity, the AUC will be equal to 0.5 , and the curve will coincide with the diagonal. A model with an AUC $>0.7$ is considered to have reasonable discrimination capacity and practical utility (Hosmer and Lemeshow 2000). To obtain a single index of the discrimination capacity of the final model, the area under the curve and the standard error was calculated using the software predictions by MedCalc (2006), which uses the maximum likelihood approach. MedCalc (2006) also provides the 95\% confidence intervals (CI) for the area. This was used to test the hypothesis that the theoretical area is 0.5 , or that the model has no discrimination capacity. If the confidence interval did not include 0.5 , then it can be concluded that the model has the ability to distinguish between presence and absence of buffel grass (Hanley and McNeil 1982).

There are various documented ways of determining quantitative probability thresholds from logistic models. For example, Austin et al. (1990) arbitrarily defined a species qualitative environmental realised niche, where the probability of finding the species is $P>0.1$, and the qualitative optimal niche at $P>0.7$. Wintle et al. (2005) recommend avoiding the use of arbitrary thresholds altogether unless the model is well calibrated, or the management costs of false-negative and false-positive prediction errors are evaluated. For this study, we followed an approach similar to Guénette and Villard (2005), and used the ROC, which assesses model performance for all possible probability thresholds. To indicate the point at which buffel grass was likely to be present in a patch of poplar box woodland, we selected the maximum accuracy threshold, at which both the false positive rate (proportion of sites where buffel grass was predicted as present but was observed as absent) and false negative rate (proportion of sites where buffel grass was predicted as absent but was observed as present) were minimised simultaneously.

Spearman rank coefficients were used to explore the relationship between percent cover of buffel grass and percent cover of native perennial grass and forb species recorded at more than six of the 60 sites. To explore the potential impact of buffel grass cover on reptile species, we used BMA to predict the probability of species occurrence using logistic regression and based on the local- and landscape-scale variables (Table 1). The analysis was conducted for reptile species detected at more than six sites. The BMA package accounts for uncertainty in model selection by combining the predictions from multiple models as weighted averages based on the Bayesian information criterion (BIC), which is analogous to the AIC. Consequently, estimates of uncertainty of model predictions are not reliant upon a single model (Raftery and Zheng 2003; Wintle et al. 2003). Bayesian inference allows the incorporation of a posterior probability, or prior belief, if knowledge or data is available. By averaging over the best models, BMA calculates a posterior probability distribution that a variable is included in the most plausible model (Raftery et al. 2006). Thus, we were able to ascertain whether buffel grass cover was an important predictor in determining reptile presence or absence if it was selected as an explanatory variable in one or more of the top five models. The estimate was averaged over the best models so that we could identify whether the relationship between species occurrence and buffel grass cover was positive or negative. We used hierarchical partitioning to identify the explained variance in reptile species presence or absence attributable to the univariate correlation with the localand landscape-scale variables. This provided a measure of the independent contribution accounted for by the buffel grass cover variable for each reptile species.

\section{Results}

Buffel grass was recorded at 26 sites, eight of which were assessed with more than $5 \%$ buffel grass cover (Fig. 2). The mean cover of buffel grass varied significantly between sites on different tenure types $\left(F_{3,56}=7.68, P<0.001\right)$ and grazing pressure categories $\left(F_{2,57}=7.83, P<0.001\right)$, but not fire intensity $\left(F_{2,57}=1.132\right.$, $P>0.05)$. Stock routes contained the highest mean cover of buffel grass, whereas it was not detected at the sites within national park and state forest (Fig. 3a). Tukey's pairwise comparison tests revealed significant differences in buffel grass cover on heavily grazed sites as compared with lightly grazed sites (Fig. 3b). Buffel grass was recorded across both burnt and unburnt sites, and cover was quite variable at sites with cool and hot burns, as can be seen by the high standard errors associated with the mean (Fig. 3c).

\section{Buffel grass in the landscape}

Two buffel grass occupancy models were generated with a $\Delta_{i}<2$ and a $w_{i}>0.1$ (models 1 and 2; Table 2). Together, both models included percent native vegetation retained within a $1-\mathrm{km}$ spatial extent, litter cover, volume of coarse woody debris and long-term mean annual rainfall as the explanatory variables influencing the probability of buffel occurring in a patch of poplar box woodland. Given there was no 'best' model, model averaging was conducted 


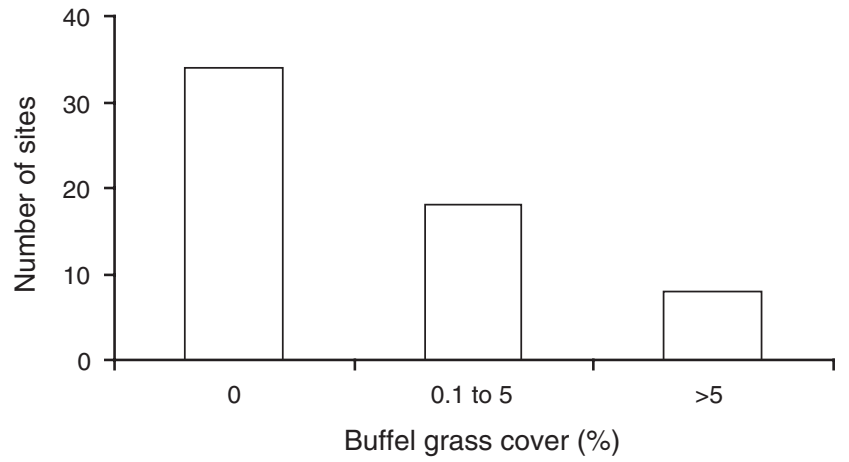

Fig. 2. Buffel grass cover per site $(n=60)$.

for the entire set of models incorporating these variables (Table 3). The AUC was calculated as $0.88 \pm 0.05$ $(\mathrm{CI}=0.78-0.95)$, suggesting the averaged-model had good discrimination capacity. The maximum accuracy threshold at which the false positive and the false negative rates were minimised was $p=0.45$

The relationship between the probability of buffel grass occurrence and each of the explanatory variables was negative. Based on hierarchical partitioning, the main contributing factor was the amount of native vegetation retained in the landscape (47\%). Using the maximum accuracy threshold, the response curve suggests that buffel grass is unlikely to occur in a patch of poplar box if native vegetation is retained at $\sim 30 \%$ in the surrounding landscape (Fig. 4). The second highest contributing variable $(25 \%)$ was litter cover. Coarse woody debris and long-term precipitation contributed $14.6 \%$ and $13 \%$, respectively. It is important to note that the $95 \%$ confidence intervals around the model-averaged estimate of coarse woody debris contained zero, suggesting that with the given data, this variable had no effect.

\section{Native grass and forb species and buffel grass}

There was a significant difference in number of native grass and forb species among the three buffel grass cover classes $\left(F_{2,57}=4.43, P<0.05\right.$; Fig. $\left.5 a\right)$, with fewer species in the highest buffel cover class $(>5 \%)$. There was no significant difference between the zero and 0.1 to $5 \%$ cover classes, with Tukey's tests showing that the significant difference was between the mean number of native ground species in the $0.1-5$ and $>5 \%$ classes.
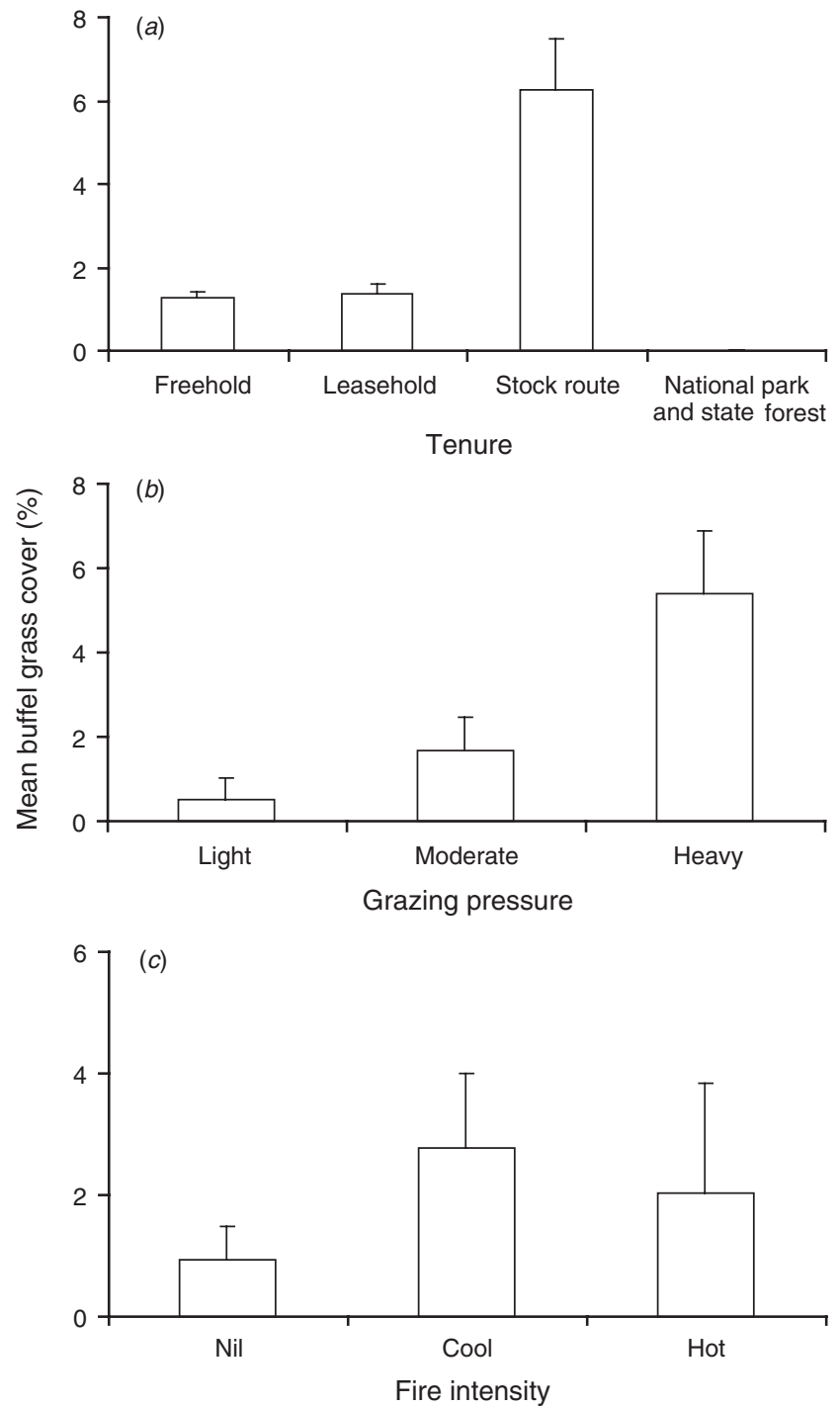

Fig. 3. Mean buffel grass cover by ( $a$ ) tenure (freehold $n=8$, leasehold $n=24$, stock route $n=19$, national park/state forest $n=9) ;(b)$ grazing pressure (light $n=22$, moderate $n=30$, heavy $n=8$ ); and (c) fire intensity (light $n=37$, moderate $n=19$, high $n=4$ ). Error bars show s.e.

Of the 30 more commonly encountered perennial grass and forb species, five had a significant correlation with buffel grass cover (Table 4). The cover of grasses Aristida caput-medusae,

Table 2. Results of the model selection analysis for probability of buffel grass occurrence in patches of poplar box Values represent the maximised $\log$-likelihood $[\log (L)]$, number of parameters $(K)$, Akaike information criterion corrected for small samples $\left(\mathrm{AIC}_{\mathrm{c}}\right)$, AIC differences $\left(\Delta_{i}\right)$ and Akaike weights $\left(w_{i}\right)$. Models are ranked in descending order relative to the $\mathrm{AIC}_{\mathrm{c}}$ of the model with the smallest $\mathrm{AIC}_{\mathrm{c}}$. The five highest ranked models are shown

\begin{tabular}{llcccrr}
\hline Model & Model variables $^{\mathrm{A}}$ & $K$ & $\log (L)$ & $\mathrm{AIC}_{\mathrm{c}}$ & $\Delta_{i}$ & $w_{i}$ \\
\hline 1 & Veg1k, Litter, CWD, Precip & 5 & -19.002 & 49.114 & 0 & 0.237 \\
2 & Veg1k, Litter, Precip & 4 & -21.056 & 50.839 & 1.725 & 0.101 \\
3 & Veg1k, Litter, PFC, CWD, Precip & 6 & -19.164 & 51.913 & 2.798 & 0.058 \\
4 & Veg1k, Litter, CWD & 4 & -21.682 & 52.092 & 2.978 & 0.054 \\
5 & Veg1k, Litter, Precip, Fire & 5 & -20.629 & 52.370 & 3.256 & 0.047
\end{tabular}

${ }^{\mathrm{A}}$ Variable codes and descriptions are provided in Table 1. 
Table 3. Model averaged estimates, unconditional standard errors, confidence intervals and independent contribution for all explanatory variables in the buffel grass binomial model

\begin{tabular}{lccccc}
\hline Model variables $^{\mathrm{A}}$ & Estimate & Unconditional SE & Upper CI & Lower CI & Contribution \\
\hline Intercept & 10.663 & 4.279 & 18.992 & 2.333 & - \\
Veg1K & -4.821 & 1.560 & -1.763 & -7.878 & 47.42 \\
Litter & -0.032 & 0.011 & -0.010 & -0.053 & 25.00 \\
CWD & -0.033 & 0.035 & 0.035 & -0.102 & 14.61 \\
Precip & -0.014 & 0.005 & -0.003 & -0.024 & 12.97 \\
\hline
\end{tabular}

${ }^{\mathrm{A}}$ Variable codes and descriptions are provided in Table 1.

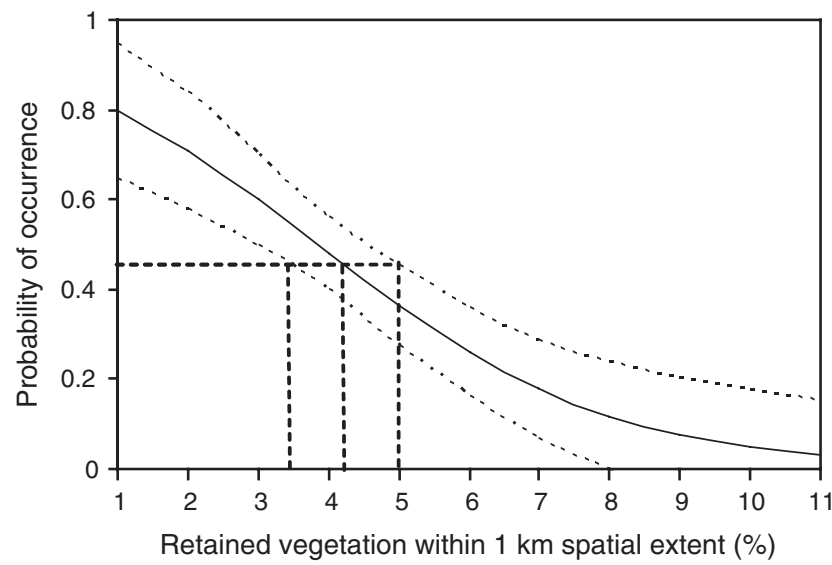

Fig. 4. Relationship between the probability of buffel grass occurrence and retained vegetation within a 1-km spatial extent. For the prediction, the other explanatory variables litter cover, precipitation and coarse woody debris were held constant at their mean. The threshold (where $p=0.45$ ) is indicated. Dashed lines around the fitted response curve represent $95 \%$ confidence intervals.

Chloris divaricata and Sporobulus caroli each increased in cover with increased buffel grass cover. Of the forbs, Cyperus gracilis and Rostellularia adscendens had a negative response to increased buffel grass cover.

\section{Reptile species and buffel grass}

There was no difference in reptile species richness among the three buffel grass cover classes $\left(F_{2,57}=1.46, P>0.05\right.$; Fig. $\left.5 b\right)$. However, of the 15 species that were detected at more than six sites, the top five most plausible models for two snakes Demansia psammophis and Furina diadema, one skink Lerista punctatovittata, and two geckos Gehyra variegata and Oedura ocellata included buffel grass cover as an explanatory variable (Table 5). The relationship between the probability of occurrence and buffel grass cover was positive for three species (D. psammophis, F. diadema and G. variegata) and negative for two species (L. punctatovittata and O. ocellata). Of the 10 localand landscape-scale variables considered, buffel grass cover returned the highest independent contribution for $F$. diadema, G. variegata, L. punctatovittata and O. ocellata (Table 5).

\section{Discussion}

Buffel grass in the landscape

Buffel grass was recorded in more than $40 \%$ of the poplar box woodland patches sampled during this study, highlighting its
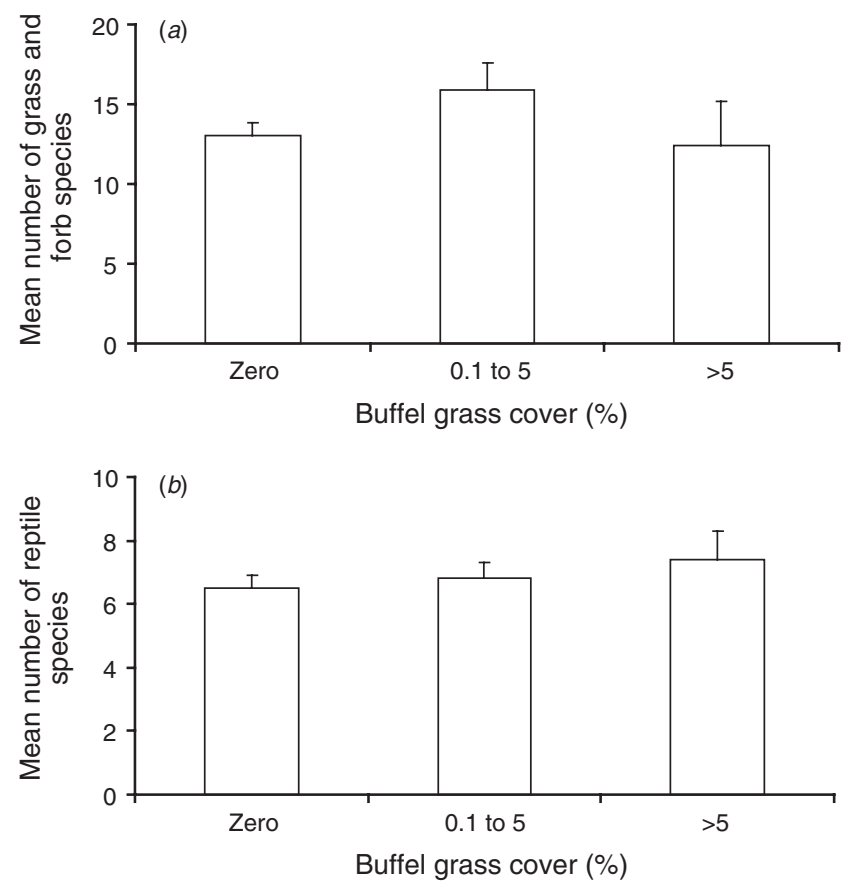

Fig. 5. Species richness for three buffel grass cover classes. (a) Mean number of native perennial grass and forb species; $(b)$ Mean number of reptile species. Error bars show s.e.

capacity to invade retained woody vegetation. This substantiates earlier observations documenting the unintentional spread of buffel grass into retained woodlands of Queensland (Christie 1975a; Fairfax and Fensham 2000; Franks 2002; Ludwig and Tongway 2002; Butler and Fairfax 2003). Buffel grass occurrence in remnants was driven by landscape-scale and localscale variables, the most influential being the amount of woody vegetation retained in the surrounding landscape. More vegetation in the landscape corresponded with a reduced likelihood of encountering buffel grass in a remnant. Presumably, two components were driving this relationship; propagule pressure and the competitive capacity of buffel grass.

Buffel grass invasiveness has predominantly been related to propagule pressure. Buffel grass has spread from sources where it has naturalised along drainage systems (Clarke et al. 2005), planted for erosion control (Daehler and Carino 1998) or accidental introductions from seed-contaminated soil (Dixon et al. 2002). However, sown pastures remain the most widely reported source of propagule pressure (Bishop et al. 1974; Mayeaux and Hamilton 1983; Franks 2002; Ludwig and 
Table 4. Spearman rank order correlations between cover of commonly encountered native perennial grass and forb species and buffel grass cover

Probability levels are: $* P<0.05 ; * * P<0.01 ; * * * P<0.001$

\begin{tabular}{|c|c|c|}
\hline Species & Spearman $R$ & $\mathrm{t}(N-2)$ \\
\hline \multicolumn{3}{|c|}{ Grasses } \\
\hline Aristida caput-medusae & 0.260 & $2.058^{*}$ \\
\hline Aristida jerichoensis var. jerichoensis & 0.138 & 1.066 \\
\hline Aristida jerichoensis var. subspinulifera & -0.017 & -0.137 \\
\hline Aristida personata & -0.058 & -0.443 \\
\hline Aristida ramosa & -0.210 & -1.636 \\
\hline Bothriochloa decipiens var. decipiens & 0.001 & 0.007 \\
\hline Chloris divaricata & 0.305 & $2.440 *$ \\
\hline Chloris ventricosa & -0.077 & -0.594 \\
\hline Cymbopogon refractus & -0.084 & -0.646 \\
\hline Enneapogon lindleyanus & -0.061 & -0.465 \\
\hline Enteropogon acicularis & 0.110 & 0.850 \\
\hline Eragrostis lacunaria & -0.100 & -0.773 \\
\hline Panicum effusum & -0.097 & -0.745 \\
\hline Paspalidium gracile & -0.046 & -0.357 \\
\hline Sporobolus caroli & 0.303 & $2.425^{*}$ \\
\hline Themeda triandra & -0.051 & -0.389 \\
\hline \multicolumn{3}{|l|}{ Forbs } \\
\hline Boerhavia dominii & 0.159 & 1.234 \\
\hline Brunoniella australis & 0.112 & 0.859 \\
\hline Chamaesyce dallachyana & -0.087 & -0.672 \\
\hline Cheilanthes distans & 0.018 & 0.140 \\
\hline Chrysocephalum apiculatum & -0.182 & -1.415 \\
\hline Cyperus gracilis & -0.337 & $-2.727 *$ \\
\hline Desmodium varians & 0.051 & 0.394 \\
\hline Einadia hastata & 0.061 & 0.472 \\
\hline Einadia nutans subsp. linifolia & -0.126 & -0.974 \\
\hline Evolvulus alsinoides & 0.102 & 0.782 \\
\hline Glycine clandestina var. sericea & 0.015 & 0.116 \\
\hline Lomandra multiflora subsp. multiflora & -0.155 & -1.199 \\
\hline Phyllanthus virgatus & -0.060 & -0.460 \\
\hline Rostellularia adscendens & -0.261 & $-2.006^{*}$ \\
\hline
\end{tabular}

Tongway 2002; Butler and Fairfax 2003). In the study region, it is, thus, intuitive that increased retained native vegetation in the landscape meant less area of sown pasture from which buffel grass seed could spread and establish. This was particularly reflected in the narrow, linear strips of retained vegetation used as travelling stock routes, which contained the highest levels of buffel grass cover. Symptomatic of edge effects, increased biomass of invasive exotic grasses along edges as compared with core area of linear remnant woodlands has been well established (Milberg and Lamont 1995; Ash et al. 1997; Franks 2002).

Litter cover was another influential variable determining buffel grass occupancy in the study, where sites with increased litter cover had less incidence of buffel grass. Litter influences the suitability of conditions required for seedling emergence, underpinning variation in the structure and composition of plant communities through competition for resources (Facelli and Pickett 1991a, 1991b; Oswalt and Oswalt 2007). Similarly, the removal of litter in North American forests through harvesting activities has been implicated as a significant mechanism facilitating the expansion of an invasive, non-native $\mathrm{C}_{4}$ grass (Oswalt and Oswalt 2007).
Table 5. Summary of logistic regression models describing presence or absence of reptile species where buffel grass cover was selected as an explanatory variable in the top five most credible models in Bayesian variable selection

\begin{tabular}{lcccr}
\hline Species & $\begin{array}{c}\text { Model } \\
\text { selection }\end{array}$ & Estimate & s.e. & $\%^{\mathrm{B}} \mathrm{I}^{\mathrm{B}}$ \\
\hline Carlia foliorum & $\mathrm{NS}$ & - & - & 7.26 \\
Carlia pectoralis & $\mathrm{NS}$ & - & - & 3.24 \\
Cryptoblepharus pannosus & $\mathrm{NS}$ & - & - & 5.28 \\
Demansia psammophis & $\mathrm{S}(1)$ & 0.081 & 0.061 & 13.85 \\
Egernia striolata & $\mathrm{NS}$ & - & - & 2.29 \\
Furina diadema & $\mathrm{S}(2)$ & 0.122 & 0.064 & 23.51 \\
Gehyra dubia & $\mathrm{NS}$ & - & - & 1.68 \\
Gehyra variegata & $\mathrm{S}(4)$ & 0.129 & 0.065 & 16.16 \\
Heteronotia binoei & $\mathrm{NS}$ & - & - & 12.84 \\
Lerista muelleri & $\mathrm{NS}$ & - & - & 4.80 \\
Lerista punctatovittata & $\mathrm{S}(2)$ & -0.087 & 0.051 & 14.20 \\
Menetia greyii & $\mathrm{NS}$ & - & - & 7.22 \\
Menetia timlowi & $\mathrm{NS}$ & - & - & 10.11 \\
Morethia boulengeri & $\mathrm{NS}$ & - & - & 5.00 \\
Oedura ocellata & $\mathrm{S}(3)$ & -0.420 & 0.354 & 24.79 \\
\hline
\end{tabular}

${ }^{\mathrm{A}}$ Whether buffel grass cover was selected (S) or not selected (NS) is indicated. The number in parentheses indicates the number of models (of the top five models) buffel grass cover was included. Model-averaged estimates and standard error (s.e.) are given for species' models where buffel grass cover was selected.

${ }^{\mathrm{B}}$ The percentage contribution of the buffel grass cover variable to the total explained variance for reptile species occupancy of poplar box patches that is attributable to independent effects $(\% \mathrm{I})$.

Other researchers have reported buffel grass exhibiting the capacity to colonise bare areas, but not densely vegetated areas (Cook and Dolby 1981; McIvor 2003), or areas with intact mid- or over-storey canopy cover (Franks 2002; Butler and Fairfax 2003). Under field conditions, litter has not specifically been implicated as having an effect on buffel grass spread. However, under experimental conditions, eucalypt litter cover has been shown to have a negative effect on buffel grass seedling emergence (Jackson 2004). The reasons for this remain unclear, although Jackson (2004) did identify increased pathogen activity typically associated with litter, as well as litter acting as a physical impediment to seedling growth, as reasonable explanations. Certainly, buffel grass seed predation by litter microfauna and pathogens has been observed in 16-year-old buffel grass siratro (Macroptilium atropurpureum) pastures, resulting in poor seedling emergence (Hacker 1989). Reduced contact with bare soil has also been implicated as a reason for poor buffel grass, and other exotic pasture species, seedling establishment in sown pastures (Cook and Dolby 1981; Cook et al. 1993). Jackson (2004) also found that buffel grass seedling emergence from bare soil was markedly faster than from under litter, and suggested that this would have a detrimental impact on its competitive capacity. If this is the case, then increased litter cover could reduce the capacity of buffel grass seeds to establish. This assumes that native grass species have a competitive advantage over buffel grass in littered environments, whereby they are not as hampered by increased levels of litter. Certain types of litter are known to depress germination and seedling establishment for certain species, including natives (Facelli and Pickett 1991a; Lenz et al. 
2003; Maret and Wilson 2005). What we need to know is the relative capacity of buffel grass to establish in remnant woodlands with increased litter cover as compared with native grass species.

In semi-arid ecosystems the timing and amount of rainfall is a major driver of vegetative response (Friedel 1991; Clarke et al. 2005). Buffel grass belongs to the $\mathrm{C}_{4}$ group of grasses which tend to respond best to summer rain. However, long-term monitoring data has shown that buffel grass responds to increases in both summer and winter rainfall, and this has allowed it to successfully compete with native herbaceous species (Clarke et al. 2005). Our long-term rainfall data was a coarse annual average based on calendar years rather than seasons, but it was still selected as an important variable explaining buffel grass occurrence. The averaged-model predicted a decrease in the incidence of buffel grass in poplar box fragments with increased long-term mean annual rain. This pattern is the reverse to that observed by Clarke et al. (2005), probably because the competitive capacity of buffel grass in the poplar box remnants was already compromised. The survival of buffel grass seedlings appear to be greatly affected by competition with established plants (McIvor 2003). The exception is during drought, when established native pasture species are weakened enough to allow successful colonisation by buffel grass, and its eventual establishment (Cavaye 1991). If so, then it would be only during times when rainfall was limited that buffel grass would get the opportunity to successfully colonise a poplar box remnant with established groundcover.

The model also predicted that coarse woody debris influenced the occupancy of buffel grass in poplar box, with more debris corresponding with a reduced probability of buffel grass occurring. However, the model confidence intervals revealed that the effect of this variable was ambiguous, and therefore this study cannot definitively demonstrate that coarse woody debris has any influence upon buffel grass occupancy. Intuitively, fire could have reduced the amount of woody debris and concurrently encouraged an increase in the distribution of buffel grass, suggesting no direct causal effect between woody debris and buffel grass occurrence but rather disparate responses by each variable to fire. However, we found no direct relationship between our fire index and buffel grass cover or with coarse woody debris volumes, suggesting either that at the time of the study fire had a minimal impact in the poplar box ecosystems or that our derived fire index was inappropriately derived. In cleared pastureland and degraded landscapes the presence of woody debris has been shown to aid colonisation of buffel grass (Bishop et al. 1974) and other vegetation (Ludwig and Tongway 1996) through mechanical effects such as seed, soil and moisture trapping. The mechanism that apparently benefits buffel grass establishment in an open paddock is likely to also assist native ground cover flora in a wooded ecosystem, further compromising the colonising capacity of buffel grass through competition. Indeed, in the poplar box woodlands in the study region, native grass and forb cover does appear to increase with more coarse woody debris (T. J. Eyre and J. Wang, unpubl. data).

Further, soil nitrogen did not appear to have a significant effect upon buffel grass presence in poplar box woodlands. Soil texture and fertility, in particular increased phosphorous and $\mathrm{pH}$ levels, have been identified as major factors influencing the efficacy of buffel grass spread into adjacent ecosystems (Christie 1975b; Christie and Moorby 1975; McIvor 1984; Cavaye 1991).
Phosphorous was not sampled during this study, and may contribute to reducing the unexplained variation in the model. It is recommended that future work investigating buffel grass spread incorporate more soil measures than were conducted by our study.

\section{Native grass and forb species and buffel grass}

We detected significant relationships between five plant species and buffel grass, and of these only two forb species displayed a negative response. Compared with other studies, the level of response between native species and buffel grass appears underwhelming, and this may reflect the fact that sampling occurred during a very low rainfall period. During our study buffel grass cover averaged $7 \%( \pm 0.28$ s.e. $)$ of total cover at sites where it was recorded. This is relatively minor when compared with levels of cover recorded in highly fragmented poplar box woodlands to the west of our study area (average of $20 \%$ cover; Franks 2002) and in remnant gidgee (Acacia cambagei) and brigalow (Acacia harpophylla) woodland north of our study region, (average of 30\% cover; Butler and Fairfax 2003). Therefore, it is possible that the levels of buffel grass cover were too low to have a discernible impact on most species.

Impacts of buffel grass establishment upon flora can be direct or indirect, influencing the structural, compositional and functional aspects of an ecosystem (Friedel et al. 2006). As a direct impact, the superior competitive capacity of established buffel grass for water and nutrients is one reason why the incidence of certain plant species decreases with increased buffel grass cover. Clarke et al. (2005) showed buffel grass directly influenced native grasses by reducing winter growth response as well as the summer growth response in forbs. Alleloepathy in buffel grass has also been implicated. Leachates from buffel grass leaves and roots have been shown to significantly reduce seed germination rates in some herbaceous species under experimental conditions (Cheam 1984a, 1984b; Nurdin and Fulbright 1990). Phytotoxicity appears to be particularly concentrated in the topmost layer in the soil profile (Cheam 1984b). This has particular ramifications for species whose seeds typically occur towards the soil surface.

Indirect impacts of buffel grass establishment, through alteration of functional components through changed fire and grazing regimes, have been more convincingly implicated by field studies as having a negative effect upon flora species (e.g. Franks 2002; Butler and Fairfax 2003). The two forb species that showed a decreaser response to buffel grass, $C$. gracilis and R. adscendens, were also shown by Fairfax and Fensham (2000) to be less abundant in pasture with more than $10 \%$ buffel grass cover compared with uncleared native pasture land. They appear to be species sensitive to disturbance, having been identified elsewhereas stock grazing decreasers (Fensham and Skull 1999; McIntyre et al. 2003), and in the case of R. adscendens, intolerant to soil disturbance and enrichment associated with exotic grass cultivation (McIntyre and Martin 2002). Similarly, the three grass species, Aristida caput-medusae, Chloris divaricata and Sporobulus caroli whose cover increased with buffel grass cover are each well known as grazing increasers (Henry et al. 1995). Therefore, our results probably reflect an ecological response to a gradient in grazing intensification, rather than any direct 
competitive association, such as allelopathy, with buffel grass. Our study was not specifically designed to address the impact of increasing buffel grass cover upon floristic species composition, and this type of study is urgently required to provide more conclusive outcomes regarding the potential impact of buffel grass on native species in remnant woodlands.

\section{Reptile species and buffel grass}

There is an extreme paucity of research identifying impacts of buffel grass on reptiles, or fauna in general. The only other published paper relating buffel grass cover to reptile species suggested increased buffel grass cover was detrimental for one species, Cryptoblepharus pannosus (syn. C. carnabyi) (Ludwig et al. 2000). Although we found no response for this particular species, our results did show that buffel grass influenced several other reptile species, suggesting a potential shift in composition and abundance of reptiles with the spread of buffel grass into remnant poplar box patches.

Of the set of variables investigated, buffel grass cover was the most influential variable for four of the more common species, with $F$. diadema and $G$. variegata each exhibiting an 'increaser' response, and L. punctatovittata and $O$. ocellata each displaying a 'decreaser' response. With the exceptions of $G$. variegata and L. punctatovittata, little is known of the ecology and habitat specialisation of these species. It is therefore difficult to ascertain the ecological reasons why these species displayed variable responses.

Gehyra variegata is a generalist arboreal gecko species, although it is also widely known to forage and utilise ground habitat (Moritz 1987; Henle 1990). It is also highly territorial, and capable of colonising vacant and highly disturbed habitat (Moritz 1987; Kitchener et al. 1988; Sarre et al. 1995). We therefore reason that an increase in ground habitat cover provided by buffel grass tussocks may provide an advantage for an opportunistic species such as $G$. variegata. The small elapid snake $F$. diadema is likewise considered to have broad habitat requirements; even tolerating suburbia in some situations (Wilson 2005). It may, thus, be responding to the structural aspects of the tussocks of buffel grass, particularly where coarse woody debris is also present (T. J. Eyre and M. F. Venz, unpubl. data).

Consequently, more specialised species occupying similar habitat niches, such as the arboreal gecko $O$. ocellata, may become displaced. Parallel increaser and decreaser effects were seen in $G$. variegata and $O$. ocellata congener $O$. reticulata in remnant woodlands of the Western Australian wheatbelt (Sarre et al. 1995). Sarre et al. (1995) found that habitat quality (measured by the number of large eucalypts) influenced ability of $O$. reticulata to persist in the remnants it shared with $G$. variegata. If a decline in habitat quality is similarly significant for $O$. ocellata in the present study, it is difficult to explain how buffel grass could be a direct agent. Decreasing numbers of O. ocellata here are more likely to be attributable to competitive interactions with $G$. variegata, or correlated with other changes in habitat quality that allow buffel grass to proliferate, such as increasing habitat fragmentation.

The fossorial skink L. punctatovittata prefers sandy to loamy soils but can exist on heavier soils where there is a thick mat of leaf litter under the base of trees and shrubs (Wilson and Knowles
1988; Wilson 2005). One of the few ecological studies on this species identified microhabitat and food to be the most important determinants for niche partitioning (Henle 1989). Buffel grass may influence the microhabitat quality of L. punctatovittata via physical means (i.e. thick root mats) or via soil nutrient depletion (Ibarra-Flores et al. 1999) impacting on its primary food source of insect larvae (Henle 1989). However, owing to the dearth of information on reptile species habitat requirements means we are limited to speculation only. Similar to our conclusions regarding buffel grass and floristic species, more in-depth research on reptile community composition and distribution along a gradient of buffel grass cover is clearly required.

\section{Management implications}

This study demonstrated that an increase in grazing pressure corresponded with an increase in the cover of buffel grass, confirming the observations by Franks (2002) and Ludwig and Tongway (2002). The 'positive feedback' between buffel grass spread and hot fires described by Butler and Fairfax (2003) appears to be just as relevant to grazing in the poplar box remnants. Conversely, fire did not appear to have much influence on buffel grass establishment. This was not entirely unexpected, as in these ecosystems continuous grazing regimes coupled with highly variable rainfall and extended dry conditions, as experienced during the study, result in limited fuel loads (Hall et al. 1994). Indeed, in the region fire has been discouraged as a management tool in buffel grass pastures due to loss of pasture nutrients and consequent reduction in cattle production (Mannetje et al. 1983). However, the link between fire management, coarse woody debris and buffel grass is worthy of further investigation in the region.

The competitive capacity of buffel grass was enhanced in the more highly modified landscapes of our study area, with an increased presence of buffel in eucalypt woodland remnants with less than $30 \%$ woody vegetation retained in the landscape. Andrén (1994) advocated a theoretical threshold of between 10 and $30 \%$ retained habitat in the landscape, at which major ecological dysfunction occurs and species are lost from the landscape. In Australia, the 30\% vegetation retention threshold has been used as a broad principle for sustainable grazing land management at the property scale (McIntyre et al. 2000; McAlpine et al. 2002). Others have provided empirical evidence that supports retention of $>30 \%$ vegetation in the landscape for the maintenance of biodiversity (Radford et al. 2005) and productivity (Walpole 1999) values. Whether this threshold will hold for other vegetation communities, in particular those with edaphic features preferred by buffel grass e.g. brigalow, remains to be tested.

In the fragmented landscapes of semi-arid Queensland in the Brigalow Bioregion, the $30 \%$ woody vegetation retention threshold provides an indicative target for the restoration of cleared habitat, at least for eucalypt-dominated ecosystems. The threshold is particularly pertinent if grazing and fire are managed at levels that maintain sufficient litter cover and do not compromise the competitive advantage of native pasture species. Thus, the retention of regrowth native vegetation to obtain at least $30 \%$ native woody vegetation cover in the landscape, and reducing grazing pressure within remnants may be the most 
effective approaches to minimising the spread of buffel grass into remnant poplar box vegetation in this region.

\section{Acknowledgements}

We warmly thank the landholders and their families for kindly allowing access to their properties for this study. Many thanks to T. Hardaker, D. Ferguson and A. Kelly for assistance in the field. The project benefited from early discussions with D. Butler, S. McIntyre and A. Leverington. Thanks to A. Lawrence, M. Kraus and J. Thiessen for GIS assistance and generation of the landscape metrics, and J. Neldner and two anonymous reviewers for comments. This study was funded and supported by Land and Water Australia Native Vegetation Program (Project QNR28), Queensland Department of Natural Resources and Mines and the Queensland Environmental Protection Agency. Reptile surveys were conducted under Ethics Permit (Activity No. BRIBIE/6/99-1).

\section{References}

Andrén, H. (1994). Effects of habitat fragmentation on birds and mammals in landscapes with different proportions of suitable habitat: a review. Oikos 71, 355-366. doi: 10.2307/3545823

Arriaga, L., Castellanos, A. E., Moreno, E., and Alarcón, J. (2004). Potential ecological distribution of alien invasive species and risk assessment: a case study of buffel grass in arid regions of Mexico. Conservation Biology 18, 1504-1514. doi: 10.1111/j.1523-1739.2004.00166.x

Ash, A. J., McIvor, J. G., Mott, J. J., and Andrew, M. H. (1997). Building grass castles: Integrating ecology and management of Australia's tropical tallgrass rangelands. The Rangeland Journal 19, 123-144. doi: 10.1071/ RJ9970123

Austin, M. P., Nicholls, A. O., and Margules, C. R. (1990). Measurement of the realized qualitative niche: environmental niches of five Eucalyptus species. Ecological Monographs 60, 161-177. doi: 10.2307/1943043

Bishop, H. G., Weston, E. J., and Sillar, D. I. (1974). Spread of Cloncurry buffel grass (Cenchrus pennisetiformis) on a river levee in north-western Queensland. Queensland Journal of Agricultural and Animal Sciences 31, 253-261.

Bostock, P., and Holland, A. E. (2007). 'Census of the Queensland Flora 2007.' (Queensland Herbarium, Environmental Protection Agency: Brisbane.)

Burnham, K. P., and Anderson, D. R. (2002). 'Model Selection and Multimodel Inference: a Practical Information-theoretic Approach.' 2nd edn. (Springer-Verlag: New York.)

Búrquez-Montijo, A., Miller, M. E., and Martínez-Yrizar, A. (2002). Mexican grasslands, thornscrub, and the transformation of the Sonoran Desert by invasive exotic buffelgrass (Pennisetum ciliare). In 'Invasive Exotic Species in the Sonoran Region'. (Ed. B. Tellman.) pp. 126-146. (University of Arizona Press and the Arizona-Sonora Desert Museum: Tucson.)

Butler, D. W., and Fairfax, R. J. (2003). Buffel grass and fire in a gidgee and brigalow woodland: a case study from central Queensland. Ecological Management \& Restoration 4, 120-125. doi: 10.1046/j.1442-8903.2003. 00146.x

Cavaye, J. M. (1991). 'The Buffel Book. A Guide to Buffel Grass Pasture Development in Queensland.' (Queensland Department of Primary Industries: Brisbane.)

Cheam, A. H. (1984a). Allelopathy in buffel grass (Cenchrus ciliaris L.) Part I. Influence of buffel grass association on calotrope (Calotropis procera (Ait.) W.T.Ait.). Australian Weeds 3, 133-136.

Cheam, A. H. (1984b). Allelopathy in buffel grass (Cenchrus ciliaris L.) Part II. Site of release and distribution of allelochemical in the soil profile. Australian Weeds 3, 137-139.
Chilcott, C. R., Owens, J. S., Silburn, D. M., and McKeon, G. M. (2004). How long will soil resources last in semi-arid grazing systems? In 'Conserving Soil and Water for Society: Sharing Solutions. Proceedings 13th International Soil Conservation Organisation Conference'. (Eds S. R. Raine, A. J. W. Biggs, N. W. Menzies, D. M. Freebairn and P. E. Tolmie.) pp. 1-6. (Australian Society of Soil Science Incorporated: Warragul, Vic.)

Christie, E. K. (1975a). A note on the significance of Eucalyptus populnea for buffel grass production in infertile semi-arid rangelands. Tropical Grassland 9, 243-248.

Christie, E. K. (1975b). A study of phosphorous nutrition and water supply on the early growth and survival of buffel grass grown on a sandy red earth from south-west Queensland. Australian Journal of Experimental Agriculture and Animal Husbandry 15, 239-249. doi: 10.1071/ EA9750239

Christie, E. K., and Moorby, J. (1975). Physiological responses of semi-arid grasses. I. The influence of phosphorous supply on growth and phosphorous absorption. Australian Journal of Agricultural Research 26, 423-436. doi: 10.1071/AR9750423

Clarke, P. J., Latz, P. K., and Albrecht, D. E. (2005). Long-term changes in semi-arid vegetation: Invasion of an exotic perennial grass has larger effects than rainfall variability. Journal of Vegetation Science 16, 237-248. doi: 10.1658/1100-9233(2005)016[0237:LCISVI]2.0. $\mathrm{CO} ; 2$

Cook, S. J., Clem, R. L., Macleod, N. D., and Walsh, P. A. (1993). Tropical pasture establishment. 7. Sowing methods for pasture establishment in northern Australia. Tropical Grasslands 27, 335-343.

Cook, S. J., and Dolby, G. R. (1981). Establishment of buffel grass, green panic and siratro from seed broadcast into a speargrass pasture in southern Queensland. Australian Journal of Agricultural Research 32, 749-759. doi: 10.1071/AR9810749

Cox, J. R., Martin-R, M. H., Ibarra-F, F. A., Fourie, J. A., Rethman, N. F. G., and Wilcox, D. G. (1988). The influence of climate and soils on the distribution of four African grasses. Journal of Range Management 41, 127-139. doi: 10.2307/3898948

Daehler, C. C., and Carino, D. A. (1998). Recent replacement of native pili grass (Heteropogon contortus) by invasive African grasses in the Hawaiian Islands. Pacific Science 53, 220-227.

Dixon, I. R., Dixon, K. W., and Barrett, M. (2002). Eradication of buffel grass (Cenchrus ciliaris) on Airlie Island, Pilbara Coast, Western Australia. In 'Turning the Tide: the Eradication of Invasive Species'. (Eds C. R. Veitch and M. N. Clout.) pp. 92-101. (IUCN SSC Invasive Species Specialist Group, IUCN: Gland, Switzerland.)

EPA (2003). '1:100 000 Survey and Mapping of Vegetation Communities and Regional Ecosystems in Queensland. Version 4.0.' (Queensland Environmental Protection Agency: Brisbane.)

ESRI (2005). 'ArcGIS Desktop. Version 9.1.' (Environmental Systems Research Institute Inc.: Redlands, CA.)

Facelli, J. M., and Pickett, S. T. A. (1991a). Plant litter: light interception and effects on an old-field plant community. Ecology 72, 1024-1031. doi: $10.2307 / 1940602$

Facelli, J. M., and Pickett, S. T. A. (1991b). Plant litter: dynamics and effects on plant community structure and dynamics. Botanical Review 57, 1-32. doi: 10.1007/BF02858763

Fairfax, R. J., and Fensham, R. J. (2000). The effects of exotic pasture development on floristic diversity in central Queensland, Australia. Biological Conservation 94, 11-21. doi: 10.1016/S0006-3207(99) 00169-X

Fensham, R. J., and Skull, S. D. (1999). Before cattle: a comparative floristic study of Eucalyptus savanna grazed by macropods and cattle in north Queensland, Australia. Biotropica 31, 37-47.

Fitzgerald, K. (1955). Buffel grass (Cenchrus ciliaris L.). Journal of Agriculture Western Australia 4, 83-91. 
Franklin, K. A., Lyons, K., Nagler, P. L., Lampkin, D., Glenn, E. P., Molina-Freaner, F., Markow, T., and Huete, A. R. (2006). Buffel grass (Pennisetum ciliare) land conversion and productivity in the plains of Sonora, Mexico. Biological Conservation 127, 62-71. doi: 10.1016/ j.biocon.2005.07.018

Franks, A. J. (2002). The ecological consequences of buffel grass Cenchrus ciliaris establishment within remnant vegetation of Queensland. Pacific Conservation Biology 8, 99-107.

Friedel, M. (1991). Range condition assessment and the concept of thresholds: a viewpoint. Journal of Range Management 44, 422-426. doi: 10.2307/ 4002737

Friedel, M., Puckey, H., O'Malley, C., Waycott, M., Smyth, A., and Miller, G. (2006). 'Buffel Grass: Both Friend and Foe. An Evaluation of the Advantages and Disadvantages of Buffel Grass use, and Recommendations for Future Research.' (Desert Knowledge Cooperative Research Centre: Alice Springs.)

Grice, A. C. (2004). Weeds and the monitoring of biodiversity in Australian rangelands. Austral Ecology 29, 51-58. doi: 10.1111/j.1442-9993. 2004.01364.x

Grice, A. C. (2006). The impacts of invasive plant species on the biodiversity of Australian rangelands. The Rangeland Journal 28, 27-35. doi: 10.1071/RJ06014

Griffin, G. F. (1993). The spread of buffel grass in inland Australia: land use conflicts. In 'Proceedings of the 10th Australian Weeds Conference and the 14th Asian Pacific Weed Science Society Conference'. (Ed. J. T. Swarbrick.) pp. 501-504. (Weed Society of Queensland: Brisbane.)

Guénette, J.-S., and Villard, M.-A. (2005). Thresholds in forest bird response to habitat alteration as quantitative targets for conservation. Conservation Biology 19, 1168-1180. doi: 10.1111/j.1523-1739.2005.00085.x

Hacker, J. B. (1989). The potential for buffel grass renewal from seed in 16-year-old buffel grass siratro pastures in south-east Queensland. Journal of Applied Ecology 26, 213-222. doi: 10.2307/2403662

Hall, T. J., Filet, P. G., Banks, B., and Silcock, R. G. (1994). State and transition models for rangelands: II. A state and transition model of the Aristida-Bothriochloa pasture community of central and southern Queensland. Tropical Grasslands 28, 270-273.

Hanley, J. A., and McNeil, B. J. (1982). The meaning and use of the area under a receiver operating characteristic (ROC) curve. Radiology 143, 29-36.

Hannah, D., Woinarski, J. C. Z., Catterall, C. P., McCosker, J. C., Thurgate, N. Y., and Fensham, R. J. (2007). Impacts of clearing, fragmentation and disturbance on the bird fauna of eucalypt savanna woodlands in central Queensland, Australia. Austral Ecology 32, 261-276. doi: 10.1111/j.1442-9993.2007.01683.x

Henle, K. (1989). Ecological segregation in a subterranean reptile assemblage in arid Australia. Amphibia-Reptilia 10, 277-295. doi: 10.1163/156853 $889 \times 00430$

Henle, K. (1990). Population ecology and life history of the arboreal gecko Gehyra variegata in arid Australia. Herpetological Monograph 4, 30-60. doi: $10.2307 / 1466967$

Henry, D. R., Hall, T. J., Jordon, D. J., Milson, J. A., Schefe, C. M., and Silcock, R. G. (1995). 'Pasture Plants of Southern Inland Queensland.' (Queensland Department of Primary Industries: Brisbane.)

Hodgkinson, K. C., Ludlow, M. M., Mott, J. J., and Baruch, Z. (1989). Comparative responses of the savanna grasses Cenchrus ciliaris and Themeda triandra to defoliation. Oecologia 79, 45-52. doi: 10.1007/ BF00378238

Hosmer, D. W., and Lemeshow, S. (2000). 'Applied Logistic Regression.' 2nd edn. (John Wiley \& Sons: New York.)

Humphreys, L. W. (1967). Buffel grass (Cenchrus ciliaris) in Australia. Tropical Grasslands 2, 123-134.

Humphries, S. E., Mitchell, D. S., and Groves, R. H. (1991). 'Plant Invasions of Australian Ecosystems: a Status Review and Management Directions.' (CSIRO: Canberra.)
Ibarra, F. A., Cox, J. R., Martin, M. H., Crowl, T. A., and Call, C. A. (1995). Predicting buffelgrass survival across a geographical and environmental gradient. Journal of Range Management 48, 53-59. doi: 10.2307/ 4002504

Ibarra-Flores, F., Cox, J. R., Martin-Rivera, M., Crowl, T. A., Norton, B. E., Banner, R. E., and Miller, R. W. (1999). Soil physicochemical changes following buffel grass establishment in Mexico. Arid Soil Research and Rehabilitation 13, 39-52. doi: 10.1080/089030699263474

Jackson, J. (2004). Impacts and management of Cenchrus ciliaris (buffel grass) as an invasive species in northern Queensland. Ph.D. Thesis, James Cook University, Townsville, Qld, Australia.

Jackson, J. (2005). Is there a relationship between herbaceous species richness and buffel grass (Cenchrus ciliaris)? Austral Ecology 30, 505-517. doi: 10.1111/j.1442-9993.2005.01465.x

Jeffrey, S. J., Carter, J. O., Moodie, K. B., and Beswick, A. R. (2001). Using spatial interpolation to construct a comprehensive archive of Australian climate data. Environmental Modelling \& Software 16, 309-330. doi: 10.1016/S1364-8152(01)00008-1

Kaur, K., Midmore, D. J., Jalota, R. K., and Ashwath, N. (2006). Pasture composition in cleared and uncleared woodlands. Australian Journal of Botany 54, 459-470. doi: 10.1071/BT05174

Kitchener, D. J., How, R. A., and Dell, J. (1988). Biology of Oedura reticulata and Gehyra variegata (Gekkonidae) in an isolated woodland of Western Australia. Journal of Herpetology 22, 401-412. doi: 10.2307/1564335

Lawson, B. E., Bryant, M. J., and Franks, A. J. (2004). Assessing the potential distribution of buffel grass (Cenchrus ciliaris L.) in Australia using a climate-soil model. Plant Protection Quarterly 19, 155-163.

Lenz, T. I., Moyle-Croft, J. L., and Facelli, J. M. (2003). Direct and indirect effects of exotic annual grasses on species composition of a South Australian grassland. Austral Ecology 28, 23-32. doi: 10.1046/j.14429993.2003.01238.x

Low, T. (1997). Tropical pasture plants as weeds. Tropical Grasslands 31, 337-343.

Low, T. (1999). 'Feral Future.' (Viking, Penguin Books Australia Ltd: Melbourne.)

Ludwig, J. A., and Tongway, D. J. (1996). Rehabilitation of semiarid landscapes in Australia. II. Restoring vegetation patches. Restoration Ecology 4, 398-406. doi: 10.1111/j.1526-100X.1996.tb00192.x

Ludwig, J. A., and Tongway, D. J. (2002). Clearing savannas for use as rangelands in Queensland: altered landscapes and water-erosion processes. The Rangeland Journal 24, 83-95. doi: 10.1071/RJ02004

Ludwig, J. A., Eager, R. W., Liedloff, A. C., McCosker, J. C., Hannah, D., Thurgate, N. Y., Woinarski, J. C. Z., and Catterall, C. P. (2000). Clearing and grazing impacts on vegetation patch structures and fauna counts in eucalypt woodland, central Queensland. Pacific Conservation Biology 6 , 254-272.

Mac Nally, R. (2000). Regression and model-building in conservation biology, biogeography and ecology: the distinction between - and reconciliation of - 'predictive' and 'explanatory' models. Biodiversity and Conservation 9, 655-671. doi: 10.1023/A:1008985925162

Mac Nally, R. (2002). Multiple regression and inference in ecology and conservation biology: further comments on identifying important predictor variables. Biodiversity and Conservation 11, 1397-1401. doi: 10.1023/A:1016250716679

Mannetje, L 't., Cook, S. J., and Wildin, J. H. (1983). The effects of fire on a buffel grass and siratro pasture. Tropical Grasslands 17, 30-39.

Maret, M. P., and Wilson, M. V. (2005). Fire and litter effects on seedling establishment in western Oregon upland prairies. Restoration Ecology 13, 562-568. doi: 10.1111/j.1526-100X.2005.00071.x

Martin, T. G., Campbell, S., and Grounds, S. (2006). Weeds of Australian rangelands. The Rangeland Journal 28, 3-26. doi: 10.1071/RJ06017

Mayeaux, H. S., and Hamilton, W. T. (1983). Response of common goldenweed (Isocoma coronopifolia) and buffel grass (Cenchrus ciliaris) to fire and soil. Weed Science 31, 337-343. 
McAlpine, C. A., Fensham, R. J., and Temple-Smith, D. E. (2002). Biodiversity conservation and vegetation clearing in Queensland: principles and thresholds. The Rangeland Journal 24, 36-55. doi: 10.1071/RJ02002

McCullagh, P., and Nelder, J. A. (1989). 'Generalized Linear Models.' (Chapman \& Hall: London.)

McGarigal, K., Cushman, S. A., Neel, M. C., and Ene, E. (2002). 'FRAGSTATS: Spatial Pattern Analysis Program for Categorical Maps.' (University of Massachusetts: Amherst.) Available at: www.umass.edu/ landeco/research/fragstats/fragstats.html (accessed 12 March 2006).

McIntyre, S., Heard, K. M., and Martin, T. G. (2003). The relative importance of cattle grazing in subtropical grasslands: does it reduce or enhance plant biodiversity? Journal of Applied Ecology 40, 445-457. doi: 10.1046/ j.1365-2664.2003.00823.x

McIntyre, S., and Martin, T. G. (2002). Managing intensive and extensive land uses to conserve grassland plants in sub-tropical eucalypt woodlands. Biological Conservation 107, 241-252. doi: 10.1016/S0006-3207(02) 00098-8

McIntyre, S., McIvor, J. G., and Macleod, N. D. (2000). Principles for sustainable grazing in eucalypt woodlands: landscape-scale indicators and the search for thresholds. In 'Management for Sustainable Ecosystems'. (Eds P. Hale, A. Petrie, D. Moloney and P. Sattler.) pp. 92-100. (University of Queensland: Brisbane.)

McIvor, J. G. (1984). Phosphorous requirements and responses of tropical pasture species: native and introduced grasses, and introduced legumes. Australian Journal of Experimental Agriculture and Animal Husbandry 24, 370-378. doi: 10.1071/EA9840370

McIvor, J. G. (1998). Pasture management in semi-arid tropical woodlands: Effects on species diversity. Australian Journal of Ecology 23, 349-364. doi: 10.1111/j.1442-9993.1998.tb00740.x

McIvor, J. G. (2003). Competition affects survival and growth of buffel grass seedlings - is buffel grass a coloniser or an invader? Tropical Grasslands 37, 176-181.

MedCalc (2006). 'Statistics for Biomedical Research. Software Manual. Version 9.1.0.1.' (Frank Schoonjans: Mariakerke, Belgium.)

Metz, C. E. (1978). Basic principles of ROC analysis. Seminars in Nuclear Medicine 8, 283-298. doi: 10.1016/S0001-2998(78)80014-2

Milberg, P., and Lamont, B. (1995). Fire enhances weed invasion of roadside vegetation in southwestern Australia. Biological Conservation 73, 45-49. doi: 10.1016/0006-3207(95)90061-6

Moritz, C. (1987). The population biology of Gehyra (Gekkonidae: Reptilia) II. Individual movements and colonisation by Gehyra variegata and G. nana. Australian Journal of Zoology 35, 587-596. doi: 10.1071/ ZO9870587

NRM (2003). 'Land Cover Changes in Queensland 1999-2001. A Statewide Land and Tree Study (SLATS) Report.' (Queensland Department of Natural Resources and Mines: Brisbane.) Available at: www.nrm.qld. gov.au/slats/pdf (accessed 25 June 2002).

Nurdin, N., and Fulbright, T. E. (1990). Germination of 2 legumes in leachate from introduced grasses. Journal of Range Management 43, 466-467. doi: $10.2307 / 3899014$

Oswalt, C. M., and Oswalt, S. N. (2007). Winter litter disturbance facilitates the spread of the nonnative invasive grass Microstegium vimineum (Trin.) A. Camus. Forest Ecology and Management 249, 199-203. doi: 10.1016/ j.foreco.2007.05.007

Paull, C. J., and Lee, G. R. (1978). Buffel grass in Queensland. Queensland Agricultural Journal 104, 57-74.
R Development Core Team (2007). 'R: A Language and Environment for Statistical Computing. Version 2.6.0.' (R Foundation for Statistical Computing.) Available at: http://cran.r-project.org (accessed 15 February 2008).

Radford, J. Q., Bennett, A. F., and Cheers, G. J. (2005). Landscape-level thresholds of habitat cover for woodland-dependent birds. Biological Conservation 124, 317-337. doi: 10.1016/j.biocon.2005.01.039

Raftery, A., Hoeting, J., Volinsky, C., Painter, I., and Yeung, K. Y. (2006). 'The Bayesian Model Averaging (BMA) Package. Version 3.03.' (R Foundation for Statistical Computing.) Available at: http://cran. r-project.org (accessed 25 June 2008).

Raftery, A. E., and Zheng, Y. Y. (2003). Discussion: performance of Bayesian model averaging. Journal of the American Statistical Association 98, 931-938. doi: 10.1198/016214503000000891

Sarre, S., Smith, G. T., and Meyers, J. A. (1995). Persistence of two species of gecko (Oedura reticulata and Gehyra variegata) in remnant habitat. Biological Conservation 71, 25-33. doi: 10.1016/0006-3207 (94)00017-K

Sheriff, D. W., and Ludlow, M. M. (1984). Physiological reactions to an imposed drought by Macroptilium atropurpureum and Cenchrus ciliaris in a mixed sward. Australian Journal of Plant Physiology 11, 23-34.

Smyth, A., Friedel, M., and O'Malley, C. (2009). The influence of buffel grass (Cenchrus ciliaris) on biodiversity in an arid Australian landscape. The Rangeland Journal 31, 307-320.

Van Wagner, C. E. (1968). The line intersect method for forest fuel sampling. Forest Science 14, 20-26.

Vesk, P. A., and Westoby, M. (2001). Predicting plant species' responses to grazing. Journal of Applied Ecology 38, 897-909. doi: 10.1046/j.13652664.2001.00646.x

Walpole, S. C. (1999). Assessment of the economic and ecological impacts of remnant vegetation on pasture productivity. Pacific Conservation Biology 5, 28-35.

Walsh, C., and Mac Nally, R. (2007). 'Hierarchical Partitioning. The hier.part Package, Version 1.0-2.' (R Foundation for Statistical Computing.) Available at: http://cran.r-project.org (accessed 25 June 2008).

Wilson, S. (2005). 'A Field Guide to the Reptiles of Queensland'. (Reed New Holland: Sydney.)

Wilson, S. K., and Knowles, D. G. (1988). 'Australia's Reptiles: a Photographic Reference to the Terrestrial Reptiles of Australia.' (William Collins: Sydney.)

Wintle, B. A., Elith, J., and Potts, J. M. (2005). Fauna habitat modelling and mapping: a review and case study in the Lower Hunter Central Coast region of NSW. Austral Ecology 30, 719-738. doi: 10.1111/j.14429993.2005.01514.x

Wintle, B. A., McCarthy, M. A., Volinsky, C. T., and Kavanagh, R. P. (2003). The use of Bayesian model averaging to better represent uncertainty in ecological models. Conservation Biology 17, 1579-1590. doi: 10.1111/ j.1523-1739.2003.00614.x

Zweig, M. H., and Campbell, G. (1993). Receiver-operating characteristic (ROC) plots: a fundamental evaluation tool in clinical medicine. Clinical Chemistry 39, 561-577.

Manuscript received 11 August 2008; accepted 4 December 2008 